\title{
Pengembangan Media Pembelajaran Kotak Komponen Ekosistem (KOKOSIS) untuk Siswa Sekolah Dasar
}

Received:

$16 / 12 / 2021$

Accepted:

$19 / 12 / 2021$

Published:

$31 / 12 / 2021$

\author{
${ }^{1}$ Candra Mahardika, ${ }^{2}$ Andika Adinanda Siswoyo \\ Universitas Trunojoyo Madura, Bangkalan, Indonesia \\ *1. $\underline{\text { candramahardika230998@gmail.com }}$
}

\begin{abstract}
The objectives of this research are (1) to find out the development of Ecosystem Component Box learning media (KOKOSIS) on the theme 8 subtheme 1 grade V at UPTD SDN Panyaksagan Klampis; (2) to know the validity, effectiveness, and attractiveness of Ecosystem Component Box learning media (KOKOSIS) at the theme 8 sub-theme 1 grade $V$ at UPTD SDN Panyaksagan Klampis. This development research uses the Borg and Gall development model. Based on the results of the research conducted, the results showed that the average percentage of KOKOSIS learning media's validity was $89 \%$, hence it can be categorized as very valid. The effectiveness of the KOKOSIS learning media which is being measured from the teacher observations is $100 \%$, hence can be categorized as very active. Meanwhile, the result of the observation on the students' activity is $98 \%$ and can also be categorized as very active. The percentage of classical completeness is $91 \%$, hence it can be categorized as completed. In conclusion, the KOKOSIS learning media can be effectively used in learning process. Furthermore, the media's attractiveness which is measured by the percentage of student questionnaire response shows that $97 \%$ of the students claimed it as attractive, thus it can be categorized as very interesting. Thus, it can be concluded that the KOKOSIS learning media is valid, effective and interesting to be applied in the Theme 8 Sub-theme 1 of ecosystem components topic for $\mathrm{V}$ grader at UPTD SDN Panyaksagan Klampis.

Keywords: Development; Instructional Media; Learning Media Ecosystem Component Box (KOKOSIS).
\end{abstract}

\begin{abstract}
Abstrak
Tujuan penelitian pengembangan ini adalah (1) mengetahui pengembangan media pembelajaran Kotak Komponen Ekosistem (KOKOSIS) pada tema 8 subtema 1 kelas V di UPTD SDN Panyaksagan Klampis, (2) mengetahui kevalidan, keefektifan, dan kemenarikan media pembelajaran Kotak Komponen Ekosistem (KOKOSIS) pada tema 8 subtema 1 kelas V di UPTD SDN Panyaksagan Klampis. Penelitian pengembangan ini menggunakan model pengembangan Borg and Gall. Berdasarkan hasil penelitian yang dilakukan, diperoleh hasil bahwa persentase kevalidan rata-rata media pembelajaran KOKOSIS sebesar 89\% dalam kategori sangat valid. Keefektifan media pembelajaran KOKOSIS diukur dari observasi guru sebesar 100\% dalam kategori sangat aktif, observasi aktivitas siswa sebesar $98 \%$ dalam kategori sangat aktif dan persentase ketuntasan klasikal sebesar 91\% dalam kategori tuntas sehingga dapat disimpulkan media pembelajaran KOKOSIS sangat efektif digunakan pada pembelajaran. Kemenarikan diukur dari persentase hasil angket respon siswa sebesar 97\% dengan kategori sangat
\end{abstract}


menarik. Berdasarkan hasil penelitian maka media pembelajaran KOKOSIS valid, efektif dan menarik digunakan pada Tema 8 Subtema 1 materi komponen ekosistem kelas V UPTD SDN Panyaksagan Klampis.

Kata kunci: Pengembangan; Media Pembelajaran; Media Pembelajaran Kotak Komponen Ekosistem (KOKOSIS).

\section{Pendahuluan}

Pembelajaran merupakan proses interaksi yang melibatkan guru sebagai pengajar dan siswa yang sedang belajar. Belajar bukan hanya sekedar duduk dikelas dan mendengarkan penjelasan yang disampaikan oleh guru akan tetapi, belajar merupakan proses perubahan pada diri individu dan individu pada lingkungnya. Pembelajaran ialah sebuah proses yang bertujuan memfasilitasi individu mengembangkan kompetensi pada ranah pengetahuan, sikap, dan keterampilan. Proses pembelajaran merupakan bagian yang penting karena di dalamnya terdapat proses interaksi antara guru dan siswa yang bertukar informasi untuk menunjang keberhasilan belajar pada suatu lingkungan belajar (Pane \& Dasopang, 2017; Wiratman et al., 2019). Sedangkan menurut (Mujtahidin, 2014) pembelajaran adalah suatu kegiatan yang dilakukan oleh guru agar tingkah laku siswa berubah ke arah yang lebih baik.

Berdasarkan penjelasan di atas dapat disimpulkan bahwa pembelajaran merupakan proses kegiatan belajar mengajar yang di dalamnya terdapat guru dan siswa. Keduanya saling melakukan kegiatan pembelajaran guna mencapai tujuan dalam pembelajaran. Akan tetapi disini guru dan siswa memiliki peran masing-masing, tidak hanya berpedoman bahwa guru ialah seseorang yang memberikan atau mentransfer ilmu pengetahuan kepada siswa dan siswa hanya sebagai penerima pengetahuan dari guru. Namun pembelajaran merupakan sebuah kegiatan yang melibatkan guru dan siswa untuk belajar bersama dan dilakukan dengan aktif antara guru dan siswa sehingga proses pembelajaran dapat berjalan dengan maksimal (Santoso, 2020). Berdasarkan paragraf sebelumnya, maka dapat disimpulkan bahwa guru bukan satusatunya sumber dalam kegiatan pembelajaran.

Siswa juga dapat memperoleh sebuah informasi dari buku, internet, majalah, koran dan lain sebagainya. Oleh karena itu pemerintah membuat dan menetapkan kurikulum yang baru yaitu kurikulum 2013 (K13) yang menerapkan pembelajaran tematik dalam kegiatan pembelajaran. Maka dengan adanya kurikulum tersebut guru lebih dituntut untuk memberikan sebuah permasalahan-permasalahan pada siswa dan siswa dituntut untuk aktif dalam memecahkan permasalahan tersebut dengan pengetahuannya sendiri. Menurut (Aisyah, 2017) pembelajaran tematik merupakan pendekatan pembelajaran yang melibatkan beberapa mata pelajaran. Dengan demikian, proses pembelajarannya dapat dijadikan pengalaman yang bermakna bagi siswa.

Penggunaan media pembelajaran dalam pembelajaran tematik juga sangat dibutuhkan oleh guru dalam menyampaikan materi pembelajaran. Tanpa adanya sebuah media pembelajaran maka kegiatan pembelajaran dirasa kurang efektif dan siswa juga akan kurang memahami materi pembelajaran dengan maksimal sehingga dapat memengaruhi tercapainya tujuan pembelajaran. Media pembelajaran merupakan sebuah alat atau perangkat yang dapat memberikan kemudahan pada siswa dalam memahami materi pelajaran yng disampaikan oleh guru (Yahya, 2019). Sedangkan menurut (Arsyad, 2015:3) mengatakan bahwa media pembelajaran secara garis besar 
adalah manusia, materi, atau kejadian yang dapat membangun kondisi sehingga membuat siswa mampu untuk memperoleh pengetahuan, sikap, dan keterampilan.

Berdasarkan hasil observasi di kelas V UPTD SDN Panyaksagan Klampis pada tanggal 25 September 2020 mengungkap bahwa pembelajaran di kelas V UPTD SDN Payaksagan Klampis sudah menerapkan kurikulum 2013. Guru hanya berpedoman pada buku siswa dan buku guru serta hanya menggunakan gambar-gambar dan papan tulis, namun saat ini gambar-gambar tersebut dirasa tidak selalu digunakan. Sedangkan hasil wawancara menyatakan bahwa guru tidak membuat media pembelajaran yang konkret dalam menyampaikan konsep materi pembelajaran. Selain itu hasil belajar siswa menunjukkan data rata-rata nilai yang diperoleh siswa masih banyak dibawah rata-rata Kriteria Ketuntasan Minimal (KKM) yang ditetapkan oleh sekolah yaitu 70. Hasil persentase nilai siswa yang mencapai KKM yaitu 36\%, sedangkan 64\% yang lain masih dibawah KKM. Hal ini membuktikan bahwasannya tingkat ketercapaian tujuan pembelajaran tidak cukup tinggi. Hal ini juga didukung dengan hasil angket yang diberikan kepada siswa, dimana sebesar 33 siswa dari 37 siswa mengungkapkan bahwa siswa merasa bosan jika guru jarang menggunakan media pembelajaran pada saat proses pembelajaran berlangsung, sedangkan 35 siswa tertarik dan menyukai proses pembelajaran yang menarik dengan menggunakan media sehingga bisa manambah minat belajar siswa terhadap materi yang disampaikan oleh guru. Berdasarkan latar belakang permasalahan diatas, peneliti menarik sebuah judul yaitu "Pengembangan Media Pembelajaran Kotak Komponen Ekosistem (KOKOSIS) untuk Siswa Sekolah Dasar".

\section{Metode Penelitian}

Model penelitian yang digunakan dalam pengembangan media pembelajaran oleh peneliti yaitu model Borg and Gall yang dimodifikasi oleh (Sugiyono, 2015). Peneliti lebih memilih model Borg and Gall dikarenakan sesuai dengan media pembelajaran yang akan digunakan peneliti untuk menguji kevalidan, keefektifan, dan kemenarikan produk yang akan digunakan di sekolah. Model Borg and Gall dalam pengembangan media ini memiliki langkah-langkah yang sistematis. Salah satu langkah-langkah dalam model Borg and Gall yaitu terdapat beberapa kali revisi yang dilakukan yang bertujuan untuk mengembangkan media pembelajaran hingga dinyatakan valid dan efektif digunakan pada saat digunakan dalam pembelajara.

Prosedur penelitian pengembangan merupakan langkah-langkah yang disusun secara sistematis dan digunakan sebagai acuan oleh peneliti dalam sebuah penelitian pengembangan ini. Berkaitan dengan penelitian pengembangan yang digunakan yaitu model Borg and Gall yang dimodifikasi oleh (Sugiyono, 2015) maka langkah-langkah yang ditempuh ialah sebagai berikut: 1) Potensi dan masalah, 2) Pengumpulan data, 3) Desain Produk,4) Validasi Desain, 5) Revisi Desain, 6) Uji coba produk, 7) Revisi produk, 8) Uji coba pemakaian, 9) Revisi produk, dan 10) Produksi Masal. Peneliti membatasi penelitian hanya pada tahap revisi produk dengan hanya membuat 1 buah produk dikarenakan keterbatasan waktu, biaya, dan tenaga. Serta media pembelajaran ini hanya 


\section{2 | Candra Mahardika dan Andika Adinanda Siswoyo}

di uji cobakan di UPTD SDN Panyaksagan. Borg and Gall menunjukkan 10 langkah dalam penelitian pengembangan dapat dibatasi, apabila sumber keuangan terbatas (Hasyim, 2016).

Desain uji coba dilakukan dalam tahap pengembangan produk media pembelajaran KOKOSIS setelah melalui tahap validasi 4 ahli yaitu ahli media pembelajaran, ahli desain pembelajaran, ahli materi pembelajaran dan ahli bahasa. Uji coba dilakukan 2 kali di UPTD SDN Panyaksagan Klampis yaitu uji coba produk dan uji coba pemakaian. Uji coba produk dilakukan setelah melalui tahap validasi dan menunjukkan hasil valid dan dapat digunakan. Uji coba pemakain dilakukan pada skala yang lebih luas untuk menguji kemenarikan dan keefektifan media KOKOSIS. Uji coba produk melibatkan 9 siswa dari 37 siswa dengan kriteri 3 siswa kemampuan tinggi, 3 siswa kemampuan sedang dan 3 siswa kemampuan rendah. Sedangkan uji coba pemakaian dilakukan dengan menggunakan jumlah yang lebih banyak dari uji coba produk yaitu 28 siswa dari 37 siswa kelas V UPTD SDN Panyaksagan Klampis.

Teknik pengumpulan data merupakan cara pengembang atau peneliti untuk mengumpulkan data yang dibutuhkan selama proses penelitian. Pengumpulan data digunakan untuk memperoleh data yang digunakan dalam penelitian, serta mengumpulkan informasi dari sumber yang di inginkan untuk memecahkan permasalahan yang ditemukan. Data diperoleh dari validator ahli media pembelajaran, ahli desain pembelajaran, ahli materi, ahli bahasa, guru dan juga siswa. Teknik pengumpulan data dalam penelitian pengembangan media pembelajaran Kotak Komponen Ekosistem (KOKOSIS) tema 8 subtema 1 berupa wawancara, observasi, angket, dan tes.

Data yang diperoleh dari penelitian dianalisis menggunakan teknik analisis data sesuai dengan bentuk datanya. Menurut (Sugiyono, 2015) analisis data merupakan analisis yang dilakukan oleh peneliti setelah data dari seluruh responden atau nara sumber sudah terkumpul. Teknik analisis data digunakan untuk mengelola atau menganalisis data yang diperoleh peneliti dalam penelitian. Terdapat dua data yang diperoleh yaitu data kualitatif dan data kuantitatif. Teknik analisis deskriptif kualitatif ini dilakukan dengan mengolah data berupa masukan, tanggapan, dan saran perbaikan yang dituangkan dalam angket para ahli. Hasil analisis data ini kemudian digunakan untuk memperbaiki produk yang dikembangkan. Teknik analisis deskriptif kuantitatif digunakan untuk mengolah data yang diperoleh melalui angket dan lembar observasi dalam bentuk deskriptif persentase. Dari beberapa hasil pengambilan data penelitian melalui angket, lembar observasi dan tes akan dipersentasekan kemudian dianalisis untuk mengetahui tingkat pencapaian yang diperoleh.

\section{Hasil}

Hasil dari media yang dikembangkan berupa produk media pembelajaran Kotak Komponen Ekosistem (KOKOSIS). Adapun hasil media pembelajaran yang dikembangkan dan sudah melalui tahap validasi ahli serta telah melalui tahap uji coba produk dan uji coba pemakaian adalah sebagai berikut: 

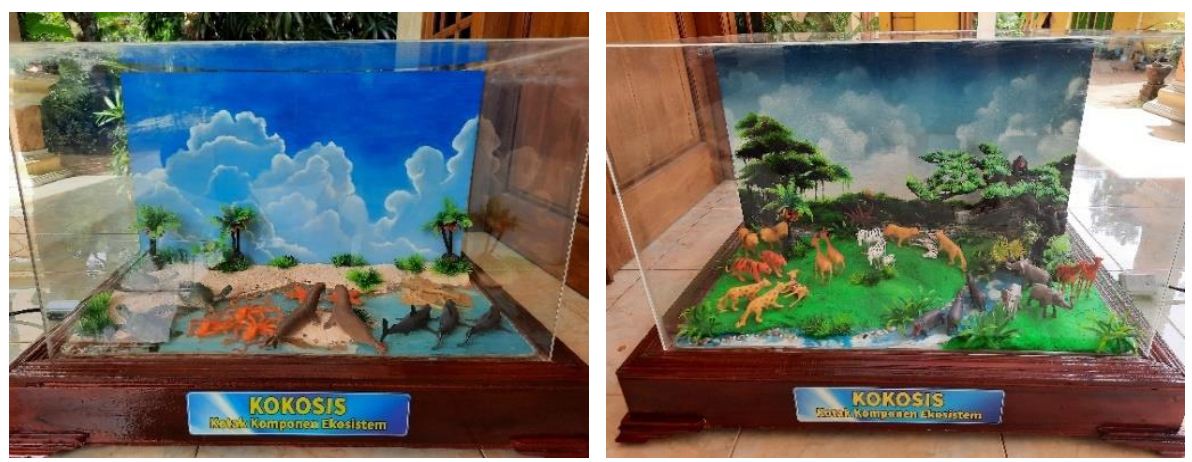

Gambar 1 Media Pembelajaran KOKOSIS

Hasil belajar siswa pada penelitian dan pengembangan ini disajikan dalam tabel hasil belajar siswa uji coba produk dan hasil belajar uji coba pemakaian sebagai berikut:

Tabel 1 Hasil Belajar Siswa Uji Coba Produk

\begin{tabular}{clccc}
\hline No & \multicolumn{1}{c}{ Nama } & Pembelajaran 1 & Pembelajaran 2 & Nilai Maksimal \\
\hline 1. & Jenny Aulia Rizky & 100 & 100 & 100 \\
2. & Mahbudin Achmad & 90 & 95 & 100 \\
& Dani & & & \\
3. & Moh. Lutfan Arif & 100 & 100 & 100 \\
& Abdillah & & & \\
4. & Moh. Sihebuddin & 80 & 95 & 100 \\
5. & Niatus Soleha & 100 & 100 & 100 \\
6. & Nur Hafifah & 100 & 100 & 100 \\
7. & Rizqi Maulana & 65 & 80 & 100 \\
8. & Rosikin & 75 & 85 & 100 \\
9. & Zilfiya & 95 & 90 & 100 \\
\hline Total Nilai & $\mathbf{8 0 5}$ & $\mathbf{8 4 5}$ & $\mathbf{9 0 0}$ \\
\hline
\end{tabular}

Tabel 2 Hasil Belajar Siswa Uji Coba Pemakaian

\begin{tabular}{clccc}
\hline No & \multicolumn{1}{c}{ Nama } & Pembelajaran 1 & Pembelajaran 2 & Nilai Maksimal \\
\hline 1. & Abd. Walid & 80 & 95 & 100 \\
2. & Achmad Dairobi & 95 & 85 & 100 \\
3. & Agus Soleh & 90 & 95 & 100 \\
4. & Ahsanul Husairi & 100 & 90 & 100 \\
5. & Alfira Nayshila Putri & 100 & 100 & 100 \\
6. & Bedrut Tamam & 100 & 100 & 100 \\
7. & Farhan Zain & 70 & 90 & 100 \\
8. & Fathur Rozi & 60 & 65 & 100 \\
9. & Hilyatus Soadah & 80 & 90 & 100 \\
10. & Himayatunnisa & 90 & 85 & 100 \\
11. & Ilzam Madani & 75 & 90 & 100 \\
12. & Inayatur Robbaniyah & 90 & 95 & 100 \\
13. & Moh Farid & 85 & 90 & 100 \\
14. & Moh Asin & 95 & 100 & 100 \\
15. & Mojehid Ansori & 100 & 90 & 100 \\
16. & Muhammad Abdul Hadi & 85 & 80 & 100 \\
17. & Muhammad Mohsin & 100 & 95 & 100 \\
18. & Nawwaf & 65 & 75 & 100 \\
19. Naylul Mawaddah & 95 & 100 & 100
\end{tabular}


44 | Candra Mahardika dan Andika Adinanda Siswoyo

\begin{tabular}{llccc} 
20. & Oktaviya Dewi & 75 & 65 & 100 \\
21. & Paiha & 90 & 95 & 100 \\
22. & Qurrotul Ainiyah & 90 & 85 & 100 \\
23. & Rayyan & 95 & 100 & 100 \\
24. & Rilham Fachrillah & 65 & 80 & 100 \\
25. & Silfia Amanda Putri & 85 & 100 & 100 \\
26. Sintya Dewi & 80 & 95 & 100 \\
27. & Subaidah & 100 & 100 & 100 \\
28. & Wafidatun Nisa & 90 & 100 & 100 \\
\hline Total Nilai & $\mathbf{2 . 4 2 5}$ & $\mathbf{2 . 5 3 0}$ & $\mathbf{2 . 8 0 0}$ \\
\hline
\end{tabular}

Sedangkan hasil analisis kevalidan, keefektifan dan kemenarikan media KOKOSIS adalah sebagai berikut:

1) Presentase Kevalidan Produk

Persentase kevalidan produk media pembelajaran KOKOSIS diperoleh dari hasil validasi para ahli yang meliputi, ahli media pembelajaran $92 \%$, ahli desain pembelajaran $83 \%$, ahli materi pembelajaran $96 \%$ dan ahli bahasa yaitu $85 \%$. Berdasarkan hasil validasi dari para ahli yang diperoleh dapat disimpulkan bahwa, produk yang dikembangkan berada pada tingkat kevalidan tinggi, sehingga media pembelajaran KOKOSIS berada pada kategori sangat valid dengan perolehan persentase validasi rata-rata yaitu $89 \%$.

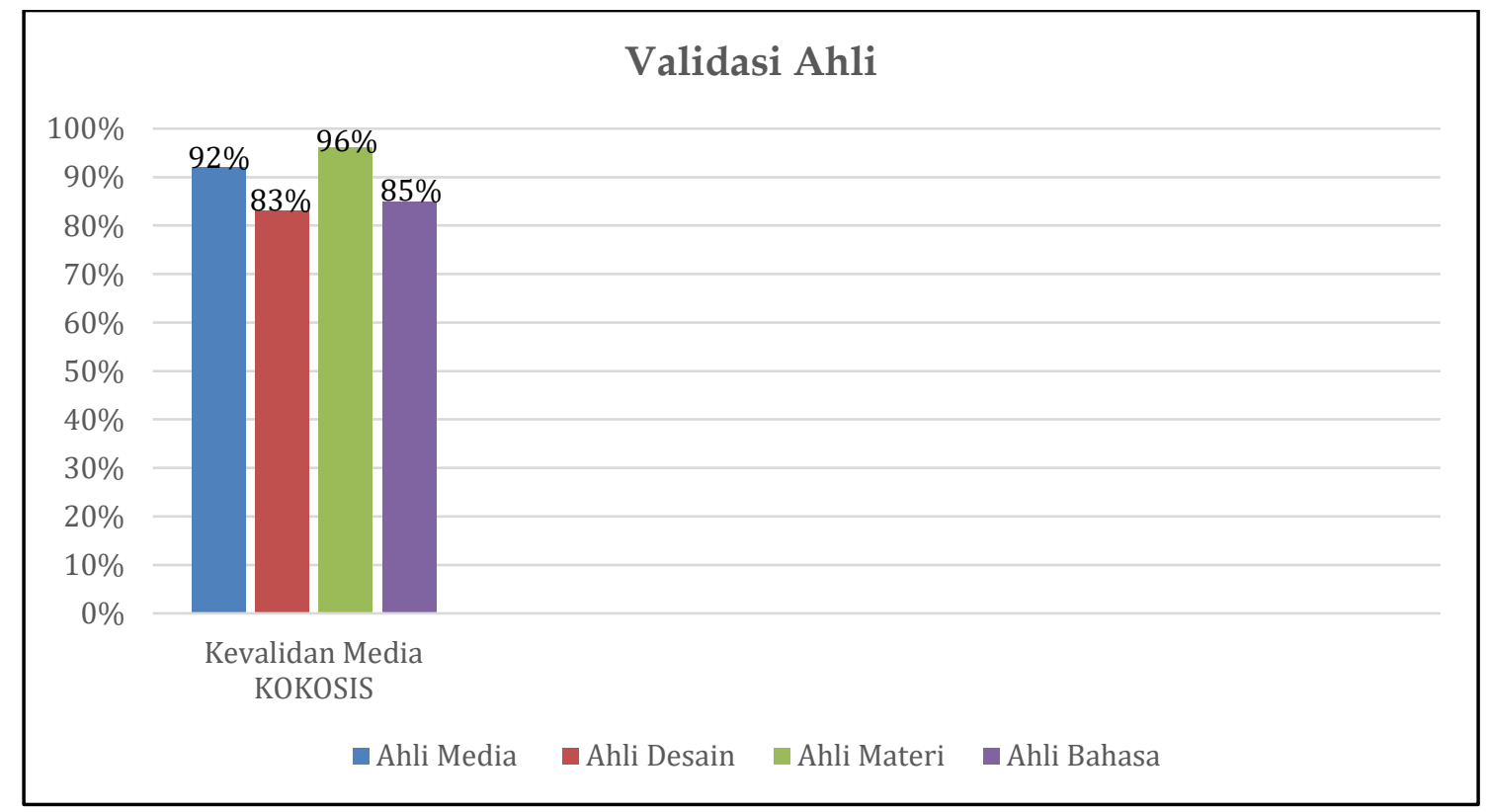

Gambar 2 Diagram Persentase Hasil Validasi Ahli

2) Presentase Keefektifan Media

Persentase keefektifan dari media pembelajaran KOKOSIS diperoleh berdasarkan penilaian observer pada lembar observasi pembelajaran (Aktivitas Guru dan Siswa) dan hasil belajar pada uji coba produk dan uji coba pemakaian. Pada uji coba produk persentase observasi aktivitas guru sebesar 97\%, persentase observasi aktivitas siswa sebesar 97\% dan persentase ketuntasan belajar klasikal sebesar 94\%. Pada uji coba pemakaian persentase observasi aktivitas guru sebesar $100 \%$, persentase observasi 
aktivitas siswa sebesar 98\% dan persentase ketuntasan belajar klasikal sebesar $91 \%$. Berikut adalah diagram persentase hasil keefektivan media KOKOSIS (Kotak Komponen Ekosistem).

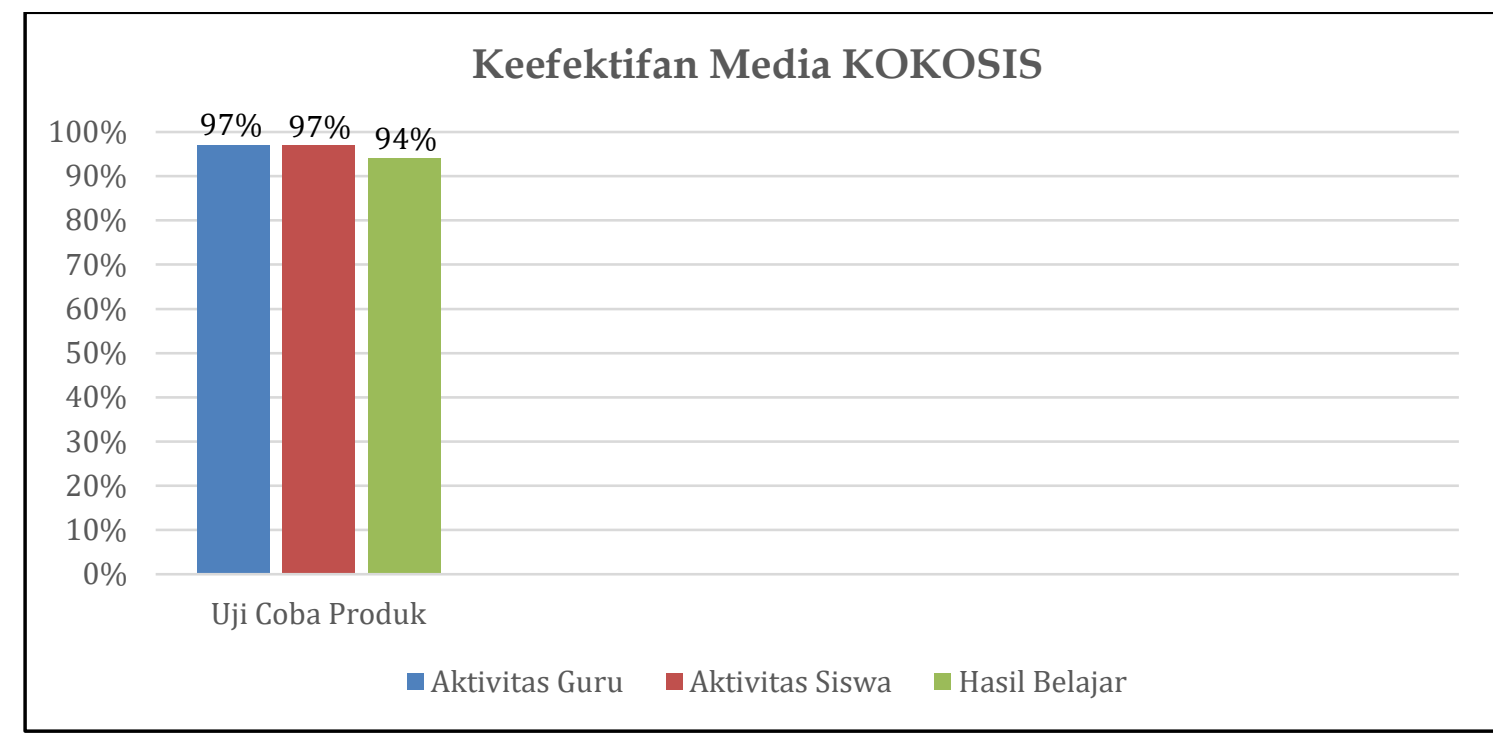

Gambar 3 Diagram Persentase Keefektifan Media KOKOSIS Uji Coba Produk

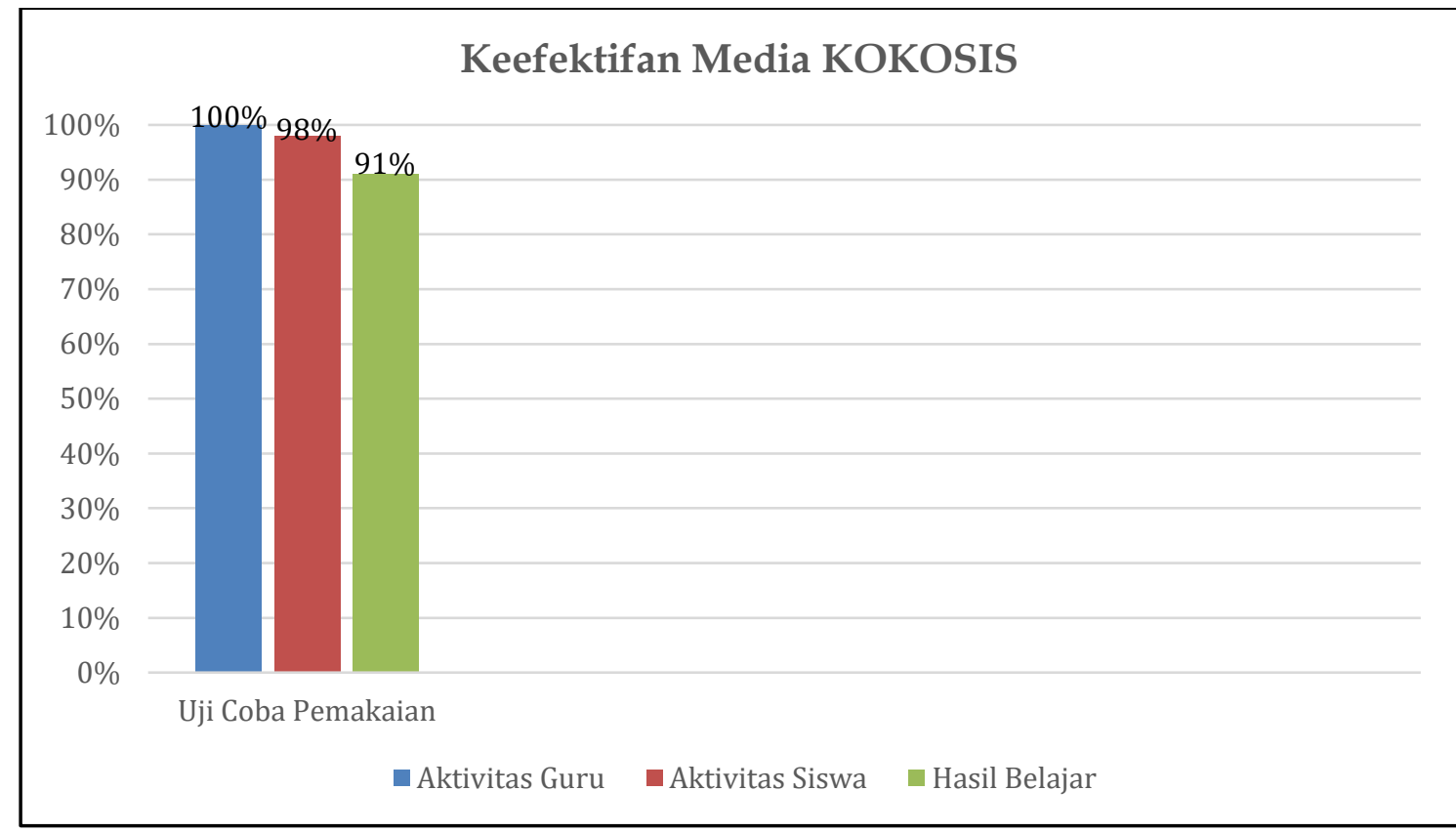

Gambar 4 Diagram Persentase Keefektifan Media KOKOSIS Uji Coba Pemakaian

3) Persentase Kemenarikan Produk

Persentase kemenarikan dari media pembelajaran KOKOSIS diperoleh berdasarkan hasil respon siswa pada uji coba produk yaitu $98 \%$ pemakaian yaitu sebesar 97\%. Dari hasil tersebut, maka dapat disimpulkan bahwa produk yang dikembangkan berada pada kategori kemenarikan yang tinggi. Berikut adalah diagram persentase hasil kemenarikan media KOKOSIS (Kotak Komponen Ekosistem). 


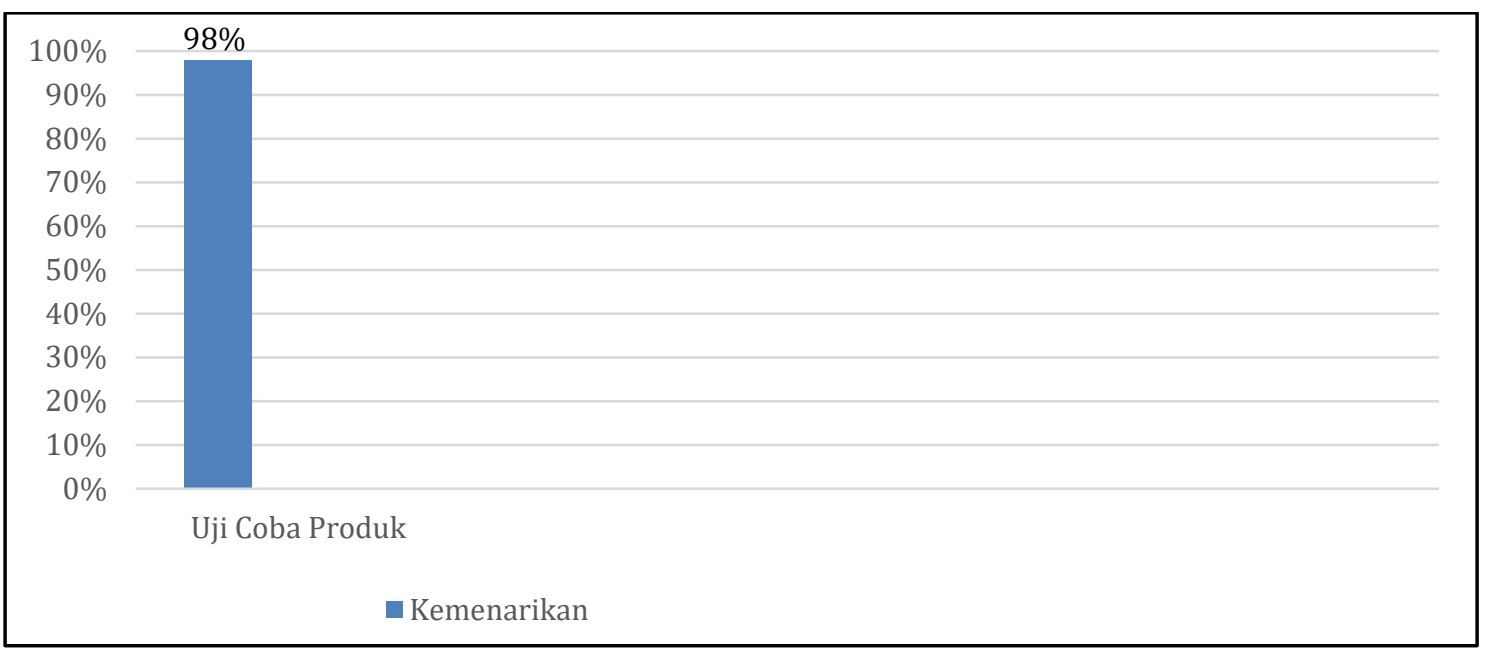

Gambar 5 Diagram Persentase Kemenarikan Media KOKOSIS Uji Coba Produk

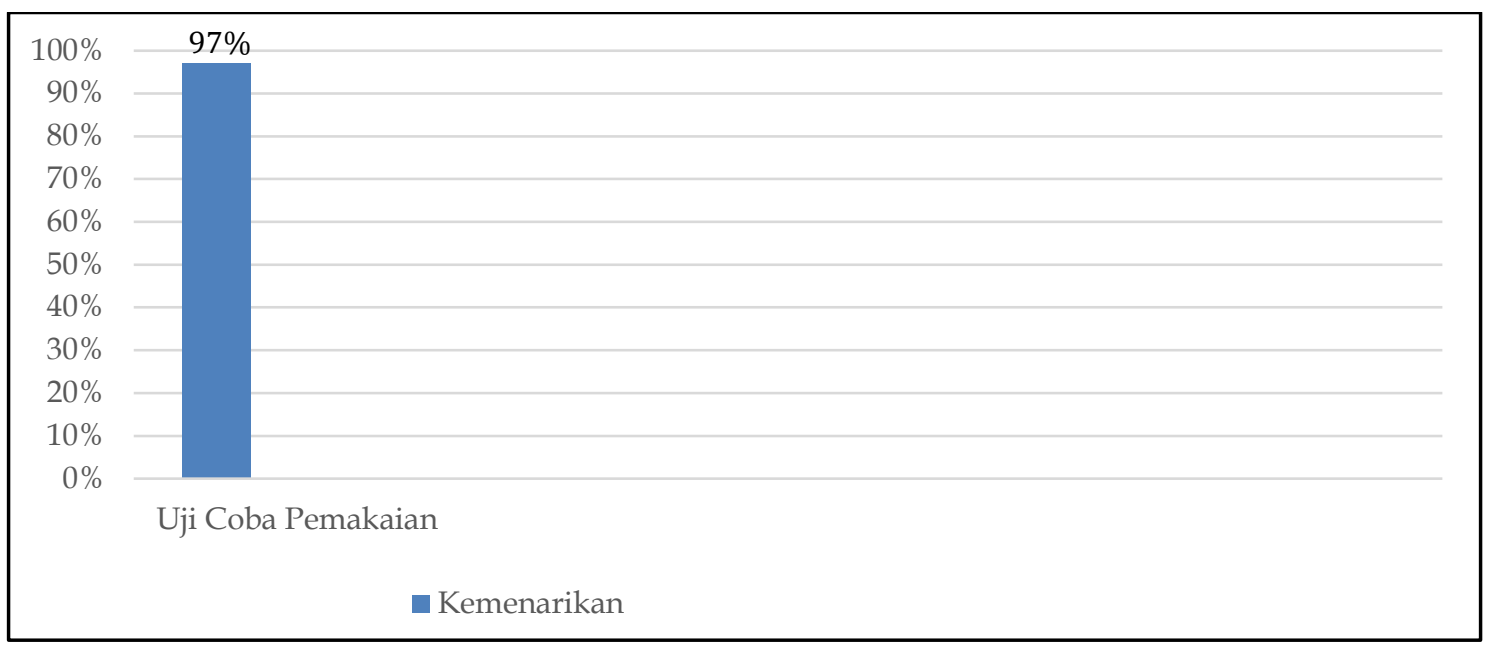

Gambar 6 Diagram Persentase Kemenarikan Media KOKOSIS Uji Coba Pemakaian

\section{Diskusi}

Media pembelajaran KOKOSIS ini telah melalui hasil uji validasi dan uji coba produk. Hasil penelitian didapatkan data bahwa secara umum produk media KOKOSIS sangat layak digunakan. Kelayakan produk media KOKOSIS dapat dilihat berdasarkan tingkat kevalidan produk, keefektifan produk dan kemenarikan produk. Hasil validasi oleh ahli media pembelajaran dari angket memperoleh persentase 92\% dengan kategori sangat valid beserta saran dan komentar ahli media. Hasil validasi oleh ahli desain pembelajaran memperoleh persentase $83 \%$ dengan kategori valid beserta saran dan komentar ahli desain pembelajaran. Hasil validasi oleh ahli materi pembelajaran memperoleh persentase $96 \%$ dengan kategori sangat valid beserta saran dan komentar ahli materi pembelajaran. Hasil validasi ahli bahasa memperoleh persentase $85 \%$ dengan kategori sangat valid beserta saran dan komentar ahli bahasa. Dari keempat validator tersebut hasil penilaian terendah diberikan oleh validator ahli desain pembelajaran yaitu 83\% dikarenakan kurang sesuainya langkah-langkah pembelajaran dengan indikator pada RPP yang akan digunakan dalam penelitian dan juga kisi-kisi penilaian kognitif yang tidak dimasukkan dalam lampiran RPP. Namun hal tersebut sudah peneliti revisi

JUDIKDAS: Jurnal Ilmu Pendidikan Dasar Indonesia

Volume 1 - No. 1 
sehingga dalam RPP sudah terdapat langkah-langkah pembelajaran yang sesuai dengan indikator pada RPP dan juga sudah terdapat kisi-kisi penilaian kognitif dalam lampiran RPP. Sedangkan dari keempat validator yang memberikan penilaian tertinggi diberikan oleh validator ahli materi pembelajaran yaitu 96\% dikarenakan sudah sangat baik dan sesuai antara materi dengan media yang akan digunakan serta sesuai dengan perangkat pembelajaran yang lainnya. Hasil rata-rata dari keempat validasi memperoleh persentase kevalidan $89 \%$ dengan kategori kevalidan menunjukkan hasil sangat valid, sehingga media pembelajaran KOKOSIS ini layak untuk digunakan dalam pembelajaran. Hasil tersebut sesuai dengan modifikasi (Akbar, 2013) media pembelajaran dapat dikatakan valid apabila secara deskriptif hasil perhitungan $\geq 68 \%$.

Hasil uji keefektifan media pembelajaran Kotak Komponen Ekosistem (KOKOSIS) pada uji coba produk didapat dari hasil lembar aktivitas guru dan siswa pembelajaran 1 dan pembelajaran 2. Hasil persentase lembar aktivitas guru pembelajaran 1 yaitu 93\% sedangkan pembelajaran 2 yaitu 100\%. Maka hasil rata-rata dari persentase lembar aktivitas guru uji coba produk pembelajaran 1 dan pembelajaran 2 yaitu 97\% dengan kategori sangat efektif. Hasil persentase aktivitas siswa pembelajaran 1 yaitu 95\% sedangkan pembelajaran 2 yaitu 99\%. Maka hasil rata-rata persentase lembar aktivitas siswa pada uji coba produk pembelajaran 1 dan pembelajaran 2 yaitu 97\% dengan kategori sangat efektif. Hasil tersebut sesuai dengan modifikasi (Akbar, 2013) bahwa media pembelajaran dapat dikatakan efektif apabila secara deskriptif hasil perhitungan aktivitas siswa guru dan aktivitas siswa $\geq 68 \%$. Selain lembar aktivitas guru dan siswa hasil uji keefektifan juga didapat dari tes hasil belajar siswa pada uji coba produk pembelajaran 1 dan pembelajaran 2. Hasil skor tes/evaluasi pembelajaran 1 yaitu 89\% sedangkan pembelajaran 2 yaitu 100\%. Maka dari kedua hasil tes/evaluasi pembelajaran 1 dan pembelajaran 2 diperoleh rata-rata yaitu 94\% dengan kategori sangat efektif. Hasil tersebut sesuai dengan yang tertera pada Depdikbud (dalam Trianto, 2008) yang menjelaskan bahwa ketuntasan klasikal harus mencapai $\geq 85 \%$.

Sedangkan hasil uji keefektifan media pembelajaran Kotak Komponen Ekosistem (KOKOSIS) pada uji coba pemakaian juga didapat dari hasil lembar aktivitas guru dan siswa pembelajaran 1 dan pembelajaran 2. Hasil persentase lembar aktivitas guru pembelajaran 1 yaitu 100\% sedangkan pembelajaran 2 yaitu 100\%. Maka hasil rata-rata dari persentase lembar aktivitas guru uji coba pemakain pembelajaran 1 dan pembelajaran 2 yaitu 100\% dengan kategori sangat efektif. Hasil persentase aktivitas siswa pembelajaran 1 yaitu 97\% sedangkan pembelajaran 2 yaitu 98\%. Maka hasil ratarata persentase lembar aktivitas siswa pada uji coba pemakaian pembelajaran 1 dan pembelajaran 2 yaitu 98\% dengan kategori sangat efektif. Hasil tersebut sesuai dengan modifikasi Akbar (2013:82) bahwa media pembelajaran dapat dikatakan efektif apabila secara deskriptif hasil perhitungan aktivitas siswa guru dan aktivitas siswa $\geq 68 \%$. Selain lembar aktivitas guru dan siswa hasil uji keefektifan juga didapat dari tes hasil belajar siswa pada uji coba pemakaian pembelajaran 1 dan pembelajaran 2. Hasil skor tes/evaluasi pembelajaran 1 yaitu $89 \%$ sedangkan pembelajaran 2 yaitu $93 \%$. Maka dari 


\section{8 | Candra Mahardika dan Andika Adinanda Siswoyo}

kedua hasil tes/evaluasi pembelajaran 1 dan pembelajaran 2 diperoleh rata-rata yaitu 91\% dengan kategori sangat efektif. Hasil tersebut sesuai dengan yang tertera pada Depdikbud (dalam Trianto, 2008) yang menjelaskan bahwa ketuntasan klasikal harus mencapai $\geq 85 \%$.

Hasil uji kemenarikan media pembelajaran Kotak komponen Ekosistem (KOKOSIS) diperoleh dari angket respon siswa baik uji coba produk dan uji coba pemakaian. Pada uji coba produk diperoleh persentase sebesar $98 \%$. Sedangkan pada uji coba pemakaian memperoleh persentase sebesar 97\%. Berdasarkan persentase kemenarikan baik uji coba produk dan uji coba pemakaian dapat dideskripsikan bahwa media pembelajaran KOKOSIS dalam kategori sangat menarik untuk digunakan pada pembelajaran. Hasil tersebut didukung oleh modifikasi Akbar (2013:82) media pembelajaran dapat dikatakan menarik apabila secara deskriptif hasil perhitungan $\geq 68 \%$.

Sedangkan hasil penelitian dan pengembangan sebelumnya yang relevan dengan penelitian ini yaitu Penelitian terdahulu dilakukan oleh Aurelia D. Asiera, tahun 2017 dengan judul "Pengembangan Media Pembelajaran papan rantai makanan subtema 3 memelihara ekosistem pada materi pokok rantai makanan pada suatu ekosistem untuk siswa kelas V Sekolah Dasar". Hasil validasi dari semua validator menunjukkan bahwa produk yang dikembangkan memiliki kualitas baik. Berdasarkan data hasil validasi oleh empat validator, skor rata-rata yang diperoleh tidak jauh berbeda. Validator pakar media konvensional diperoleh skor rata-rata 4,50 dan 4,60 (sangat baik). Sementara validator guru kelas V SD diperoleh skor 4,10 dan 3,50 dengan kategori "baik". Berdasarkan pada skor rata-rata dari keempat validator tersebut diperoleh skor rata-rata 4,17. Jika dikonversikan dalam data kualitatif, skor rata-rata 4,17 dikategorikan "baik".

Penelitian terdahulu selanjutnya dilakukan oleh Fahrul Rozi Yahya, tahun 2019 dengan judul "Pengembangan Media Pembelajaran Tiga Dimensi Tema Ekosistem Subtema Komponen Ekosistem Mata Pelajaran IPA Kelas V MI Tarbiyatul Huda Malang". Hasil penelitian pengembangan media tiga dimensi materi IPA tema 5 subtema 1 pembelajaran 2 tentang komponen ekosistem memenuhi kriteria valid dengan uji ahli desain media mencapai tingkat kevalidan $80 \%$, ahli materi mencapai $88 \%$, dan ahli pembelajaran mencapai $90 \%$. Nilai rata-rata pretest kelas kontrol 61, dan posttestnya mencapai 85. Nilai rata-rata kelas eksperimen mencapai 64,5 dan hasil posttestnya mencapai 95. Pada uji-t diperoleh $t_{\text {hitung }}$ sebesar 5,649 dan $t_{\text {tabel }}$ mencapai 2,021 . Hasil hipotesis menunjukkan bahwa ha diterima karena $t_{\text {hitung }}$ lebih besar dari pada $t_{\text {tabel }}$. Maka dapat disimpulkan terdapat peningkatan motivasi belajar siswa yang dapat dilihat dari hasil belajarnya sebelum dan sesudah menggunakan media pembelajaran tiga dimensi pada siswa kelas V MI Tarbiyatul Huda Arjowinangun Malang.

Penelitian terdahulu juga dilakukan oleh Dady Mukti Prabowo, tahun 2017 dengan judul "Pengembangan Media Diorama 3 Dimensi Dalam Pembelajaran IPA Materi Ekosistem Kelas V SDN Kalibanteng Kidul 02 Semarang". Penelitian ini 
menunjukkan bahwa media diorama 3 dimensi layak digunakan dengan persentase penilaian validasi ahli media $94 \%$, ahli materi $97 \%$, parktisi media $97 \%$, dan parktisi materi 93\% dengan uji T mendapatkan hasil $t_{\text {hitung }}$ yaitu 7,396 lebih besar dari $t_{\text {tabel }}$ yaitu 1,671 dan uji N-Gain sebesar 0,7063 dengan kriteria tinggi. Hasil dari penelitian ini adalah media diorama 3 dimensi efektif digunakan pada pembelajaran IPA terhadap hasil belajar siswa kelas V SDN Kalibanteng Kidul 02 Semarang.

\section{Kesimpulan}

Produk yang dikembangkan dalam penelitian dan pengembangan ini berupa media pembelajaran Kotak Komponen Ekosistem (KOKOSIS) yang merupakan media pembelajaran tiga dimensi jenis diorama. Model penelitian yang digunakan oleh peneliti dalam penelitian dan pengembangan media pembelajaran KOKOSIS yaitu model Borg and Gall yang dimodifikasi oleh (Sigoyono, 2015). Media pembelajaran KOKOSIS ini dapat digunakan pada pembelajaran materi komponen ekosistem, yang diuji cobakan pada siswa kelas V di UPTD SDN Panyaksagan Klampis. Media pembelajaran KOKOSIS diharapkan dapat menjadi media pembelajaran yang dapat memudahkan siswa dan guru dalam proses pembelajaran serta dapat menarik perhatian siswa dalam belajar, dan dapat menciptakan suasana belajar yang menyenangkan sehingga dapat meningkatkan hasil belajar siswa. Media pembelajaran KOKOSIS merupakan media yang dapat digunakan guru untuk mempermudah dalam proses penyampaian materi pembelajaran, serta untuk menarik perhatian dan memotivasi belajar siswa.

Saran pemanfaatan produk dari pengembangan media pembelajaran KOKOSIS sebagai media pembelajaran pada kelas V Sekolah Dasar adalah produk yang berupa media pembelajaran KOKOSIS dapat dijadikan sebagai salah satu referensi guru terkait media pembelajaran tentang komponen ekosistem. Produk media pembelajaran KOKOSIS akan lebih bermanfaat, jika digunakan dengan bebantuan buku petunjuk penggunaan media pembelajaran KOKOSIS. Produk media pembelajaran KOKOSIS dapat digunakan untuk menarik minat dan perhatian siswa dalam pembelajaran. Penggunaan media pembelajaran KOKOSIS akan lebih bermakna jika melibatkan siswa dalam proses pembelajaran. Penggunaan produk media pembelajaran KOKOSIS akan lebih bermanfaat, jika pada penyajian materi menggunakan strategi, metode dan model pembelajaran yang kreatif. Sehingga siswa tidak mudah bosan dalam mengikuti proses pembelajaran.

\section{Referensi}

Aisyah, Siti. (2014). Pembelajaran Terpadu di SD. Tanggerang Selatan: Universitas Terbuka.

Akbar, Sa'dun. (2013). Instrumen Perangkat Pembelajaran. Bandung: PT Remaja Rosdakarya.

Arsyad, Azhar. (2016). Media Pembelajaran. Jakarta: PT Rajagrafindo Persada. 


\section{0 | Candra Mahardika dan Andika Adinanda Siswoyo}

Asiera, A.D., (2017). Pengembangan Media Pembelajaran Papan Rantai Makanan Subtema 3 Memelihara Ekosistem Pada Materi Pokok Rantai Makanan Pada Suatu Ekosistem Untuk Siswa Kelas V Sekolah Dasar. Skripsi. Fakultas Keguruan dan Ilmu Pendidikan. Pendidikan Guru Sekolah Dasar, Universitas Sanata Dharma, Yogyakarta.

Fitriani, N. (2017). Pengembangan Media Pembelajaran Maket Ekosistem Untuk Kelas V SD Yamastho Surabaya. Skripsi. Fakultas Keguruan dan ILmu Pendidikan, Malang.

Mujtahidin. (2014). Teori Belajar dan Pembelajaran. Surabaya: CV Salsabila Putra Pratama.

Pane, A., \& Dasopang, M. D. (2017). BELAJAR DAN PEMBELAJARAN. FITRAH: Jurnal Kajian Ilmu-Ilmu Keislaman, 3(2), 333-352. https://doi.org/10.24952/FITRAH.V3I2.945.

Prabowo, D.M., (2017). Pengembangan Media Diorama 3 Dimensi Dalam Pembelajaran IPA Materi Ekosistem kelas V SDN Kalibanteng Kidul 02 Semarang. Skripsi. Fakultas Ilmu Pendidikan. Pendidikan Guru Sekolah Dasar, Universitas Negeri Semarang, Semarang.

Rahayu, E dkk., (2018). Pemahaman Tentang Lingkungan Berkelanjutan. Jurnal. Departemen Arsitektur, Fakultas Teknik, Universitas Diponegoro, Semarang.

Santoso, A.B., (2020). Pengembangan Media Pembelajaran Diorama "SIBANSOR" (Simulasi Banjir dan Tanah Longsor) Tema 3 Subtema 3 Pembelajaran 2 UPTD SDN Jaddih 2 Socah. Skripsi. Fakultas Ilmu Pendidikan. Pendidikan Guru Sekolah Dasar, Universitas Trunojoyo Madura, Madura.

Slameto. (2015). Belajar dan Faktor-faktor yang Mempengaruhi. Jakarta: Rineka Cipta.

Sudjana \& Rivai. (2010). Media Pengajaran. Bandung: Sinar Baru Algesindo.

Sugiyono. 2015. Metode Penelitian Pendidikan Pendekatan Kualitatif, Kuantitatif, dan RED. Bandung: Alfabeta.

Trianto. (2009). Mendesain Model Pembelajaran Inovatif-Progresif, Konsep, Lamdasan, dan Implementasinya pada Kurikulum Tingkat Satuan Pendidikan (KTSP). Jakarta: PT Kencana Prenadamedia Group Jurnal.

Wiratman, A., Mustaji, M., \& Widodo, W. (2019). The effect of activity sheet based on outdoor learning on student's science process skills. Journal of Physics: Conference Series, 1157(2), 022007. https:/ / doi.org/10.1088/1742-6596/1157/2/022007

Yahya, F.R., (2019). Pengembangan Media Pembelajaran Tiga Dimensi Tema Ekosistem Subtema Komponen Ekosistem Mata Pelajaran IPA Kelas V MI Tarbiyatul Huda Malang. Skripsi. Fakultas Ilmu Tarbiyah dan Keguruan. Pendidikan Guru Madrasah Ibtidaiyah, Universitas Islam Negeri Maulana Malik Ibrahim Malang, Malang. 